УДК 371.3::82

821.133.1.09-14 Бодлер Ш.

821.163.42.09-14 Матош А. Г. https://doi.org/10.18485/kij.2018.65.1_2.16

СОФИЈА П. СИМОВИЋ

Универзитет у Београду

Филолошки факултет, студент докторских студија
Оригинални научни рад

Примљен: 17. 04. 2018.

Прихваћен: 26. 05. 2018.

\title{
ПРОУЧАВАҢЕ ЛИРИКЕ У НАСТАВИ КЬИЖЕВНОСТИ: КОМПАРАТИВНИ ПРИСТУП НА ПРИМЕРУ ПЕСАМА „ВЕЗЕ” ШАРЛА БОДЛЕРА И ,ЈЕСЕЊЕ ВЕЧЕ” АНТУНА ГУСТАВА МАТОША
}

\begin{abstract}
У овом раду биће представљен ток наставног часа на коме се компаративним методом проучавају песме „Везе” Шарла Бодлера и „Јесење вече” Антуна Густава Матоша. На самом почетку рада биће дат књижевнотеоријски преглед карактеристика лирике које овај род одвајају од других књижевних родова. Потом ће бити речи о специфичностима и проблемима проучавања лирике у средњој школи, као и о важности ваљаног мотивисања ученика за читање, доживљавање и интерпретацију лирске песме, с обзиром на то да овај жанр ђацима није омиљен за наставно проучавање. Нарочита пажња посвећена је многобројним наставним циљевима који се остварују адекватним методичким приступом поезији. У следећем одељку установљује се разлика између затвореног и отвореног приступа књижевном тексту, те се утврђује да су интертекстуалност и компаративно сагледавање литерарних проблема неопходни у савременој настави књижевности. У наредном делу рада приказани су методички подстицаји и радни налози који ће омогућити квалитетну динамику интерпретације поменуте Бодлерове и Матошеве песме. У средишту истраживачког интересовања наћи ће се тематско-мотивске и формално-стилске особености песама, које могу послужити као окоснице наставног проучавања. На крају се закључује да ће, након поредбеног тумачења песме хрватског и француског модернисте, ученици бити подстакнути на ширење читалачких интересовања везаних за поезију, као и на реализацију стваралачких активности поводом тумачења песничких остварења.
\end{abstract}

Кључне речи: методика, настава, модерна, поезија, јужнословенска књижевност, А. Г. Матош, Шарл Бодлер, компаративни приступ. 


\section{1. Теоријска разматрања о природи лирике и модерног песништва}

Подела књижевности на епику, лирику и драму прихваћена је у нашој култури још од времена антике. Поставка ренесансног теоретичара Гваринија заснована је на односу песника према певању. У драми песник пушта да говоре други, у епу говори сам, али пушта и друге да говоре, док у лирској песми песник говори потпуно сам (Миловановић 2016: 35). Лирска песма је уметност тренутка у којем се згушњавају емоционално и мисаоно искуство песниковог ,ја”, па се стога њена структура разликује од структуре епског и драмског дела. У структури лирске песме ишчезавају догађаји као покретачи, и она се првенствено изграђује као емоционално интонирана слика, као музика песничког говора која изражава унутрашњи свет лирског субјекта (Росандић 1988: 387). Музика и слика су, дакле, два најважнија елемента лирске структуре. Посебност лирике у односу на друге књижевне радове огледа се у другачијем звучању од прозног говора (мелодиозност, музикалност), у другачијој организацији језика, у згуснутости израза и његовој семантичкој слојевитости, као и у сликовитости, експресивности и сугестивности (Росандић 1988: 383). У лирици је у првом плану посебно богатство људске свести: емоционално обојена размишљања, енергични подстицаји, импресије, ирационални осећаји, тежње. Ако је у лирском тексту и приметан какав сижејни ток, он је шкрт и без детаљнијег прецизирања (Миловановић 2016: 37). Субјективност су лирици приписивали Шлегел, Шелинг, Хегел, Фишер (Миловановић 2016: 38). Лирика се не повлачи у сферу људске психологије, већ њу привлаче душевна стања као појавности човекове усредсређености на спољашњу реалност. Лирика је кадра да искаже просторно-временске представе, повеже осећања са чињеницама природе и свакодневице, историје и савремености (Миловановић 2016: 40).

Појава модерне лирике у светској књижевности означава разлаз са традицијом лирске поезије и радикалну промену односа према језику. Како у погледу света, тако и у погледу језика, у лирици доминира, од три могућа вида лирског певања - осећања, посматрања и преображавања - овај последњи (Фридрих 2003: 15). Процес реформе лирског песништва започет је са Шарлом Бодлером, а настављен са Артуром Рембоом и Стефаном Малармеом. Бодлер је желео да искаже посебност модерног уметника, његову способност да у пустињи велеграда не види само пропаст човека него и да наслути до сада неоткривену тајанствену лепоту (Фридрих 2003: 15). 


\section{2. Проучавање лирске песме у настави и место компаративног приступа у њему}

Научна истраживања и методичка пракса показују да лирска песма ученицима није омиљени жанр за проучавање у школи. Новија методика наставе књижевности поклања изузетну пажњу књижевним интересовањима ученика, а резултати разних истраживања читалачких интересовања показују да ученици најрадије читају роман и приповетку, док их у знатно мањој мери привлачи лирска поезија и драма (Росандић 1988: 379). Ситуација је још више забрињавајућа за песнике модерне. Емпиријско истраживање које је за потребе докторске дисертације спровела Сања Голијанин-Елез показује да су ученици у круг своје блискости, емпатије и пројектовања у свет уметничког дела у већини издвојили послератну српску поезију, док је поезија модерне ученицима тежа и отуђенија (Голијанин-Елез 2009: 387). Задаци интерпретатора књижевног текста у науци о књижевности и у настави се знатно разликују. Уобичајено је мишљење да интерпретатор поезије у науци врши студиознију, строжу и развијенију анализу од оне коју је могуће извести у настави (Илић 1980: 130). Књижевни критичар треба да буде један од оних ретких читалаца који могу чути песништво јер су саобразно њему расположени (Штајгер 1978: 71). Проучавалац поезије треба да рекреира доминантну лирску атмосферу песме у свом духу, прожимајући се са текстом. Између елемената који чине поетски свет и тумача не сме бити одстојања (Штајгер 1978: 71). Не сме се ипак заборавити да наставник има низ обавеза при интерпретирању поезије са којима се научник не сусреће: наставник не само да мора да употреби научно исправан приступ тексту него је дужан да обезбеди да то учине и његови ученици у границама својих могућности; научник изриче судове о тексту сам, док наставник подстиче ученике да самостално запажају, притом водећи рачуна о њиховом суђењу о тексту (Илић 1980: 130). Због свега наведеног, наставно проучавање књижевности и лирике, као посебно захтевног књижевног рода за тумачење, изискује изузетну стручност наставника и избор адекватних метода приступа поетском тексту. Методички приступ лирској поезији изграђује се на предлошку књижевне науке, психолошких, педагошких и сазнајних одредница (Росандић 1975: 8). Својим значењем, емоционалношћу, сликовитошћу и музикалношћу песнички језик побуђује естетске емоције. Захваљујући тим својствима, песничка се реч намеће, изазива пажњу, покреће асоцијације, буди мисли. Њена моћ информисања вишеструко је већа него у обичном комуникативном језику. У поезији језик има конотативну и естетску функцију (Росандић 1988: 399). Уочавање односа међу речима и откривање њиховог значења суптилан је посао школске интерпретације. При интерпретацији песничког језика треба зауставити ученике пред његовим лепотама, објаснити им њихово значење, функцију у песничком делу, тј. конкретизацију песникових доживљаја и спознаја, али и мотивисати ученике да изразе свој однос према песничком језику (своје емоције, мисли и асоцијације). 
Многобројни образовни, васпитни и функционални циљеви остварују се у настави тумачењем поезије. Лирска песма својом многозначношћу и вишезначношћу побуђује радозналост ученика за све што га окружује (Миловановић 2016: 79). Проницањем у песничке слике, ђаци уче како да препознају уметнички лепо и активирају имагинацију, која се у континуираном сусрету са лириком интензивно развија. Дајући одговор лирској песми, унутрашњи свет младог читаоца постаје префињенији, богатији и племенитији, што проузрокује остваривање важних циљева: развијање скривених снага и талената ученика, подстицање стваралачког рада, култивисање читалачког искуства, стварање трајне читалачке навике, развијање језичког, литерарног и чулног сензибилитета, као и стицање уметничког укуса. Проучавање лирске песме подстиче вољну активност и истраживачки дух ученика, као и његову жељу да независно и самостално доноси закључке и долази до истине. Тумачење поезије омогућава развијање критичког мишљења, оспособљавање да се људи и феномени сагледају са више становишта, стварање потпунијег погледа на стварност, стицање самосвести, овладавање врхунским могућностима језика, проширивање интелектуалног хоризонта. Сазнавање важнијих уметничких чинилаца у лирској песми свестрано ангажује личност младог човека, који потом формира критички однос према ставовима лирског субјекта. Поезија снажи емпатију ученика, а утиче и на развој сензибилитета, племенитости и свестраности. Више од било ког књижевноуметничког текста, лирика показује праву вредност језика, а изучавањем језика лирике ученик схвата његову творачку снагу (Миловановић 2016: 79). Наставно проучавање књижевности се темељи на читању, а развијање читалачког умећа и стварање читалачких навика себи је поставила као примарни задатак (Николић 2009: 250). Читање, доживљавање и проучавање поезије у настави треба да развије трајно интересовање за уметност речи и смисао за вредновање књижевних дела, али и да потпомогне ученицима у формирању животних ставова. Ако је створила активног и посвећеног читаоца, настава књижевности остварила је дугорочан и далекосежан циљ (Бајић 2004: 14).

Пре него што се уведе појам компаративног приступа у настави књижевности, потребно је да се разграниче термини отворене и затворене интерпретације песничког текста. Песничко остварење може се посматрати као изолована уметничка чињеница и тумачити само у оквиру семантике датог текста, што су одлике затворене интерпретације (Тарановски 1982: 51). Отворена анализа поетског текста пак подразумева широки контекст остварен у делу других писаца, што нас приближава продубљенијем схватању система песничких слика у том тексту (Тарановски 1982: 51). На разлици између затворене и отворене интерпретације почива књижевнотеоријска дисциплина - теорија цитатности, која нам омогућава да књижевност посматрамо из сасвим посебног угла. Из перспективе интерлитерарних цитата књижевна култура разоткрива се као велика национална и светска интертекстуална заједница, у којој текстови ступају у цитатне суодносе с ближим и даљим, млађим или старијим књижевним текстовима (Ораић-Толић 1999: 25). Интертекстуална заједница постаје тим видљи- 
вија што поезију можемо сматрати као врсту уметничког стваралаштва у коме се из наслеђа преузимају сами типови и облици говора који се у те облике уносе. Постављање текста у контекст (известан број текстова који садрже сличне теме и мотиве) јесте услов да се све оно што је смештено у сферу потенцијалности преведе у сферу реално установљивих значења једног књижевног текста, ка којем треба да тежи свако тумачење (Голијанин-Елез 2009: 84). Компаративни и интертекстуални приступ нераскидиво су везани један за други, будући да се у основи интертекстуалног приступа налази компаративно посматрање двају или више текстова. У следећем одељку рада биће речи о поредбеном тумачењу репрезентативних песама Шарла Бодлера и А. Г. Матоша. Бодлерову песму „Везе” посматраћемо као хипотекст (подтекст - већ постојећи текст одражен у новом тексту (Тарановски 1982: 38)) Матошеве песме „Јесење вече”. Пажљивом компаративном анализом, утврдићемо однос двају књижевних текстова, сличности и разлике између њих, а и дефинисаћемо шта је Матош црпео из бодлеровске традиције песништва. Компаративни приступ у настави сврсисходан је због тога што омогућује остваривање принципа поступности и систематичности, будући да се ученици крећу од познатог ка непознатом, што у знатној мери мотивише ученике. Компаративна анализа двеју песама омогућава и остваривање многобројних функционалних циљева, попут аналитичкосинтетичког мишљења, перцептивних способности и критичког мишљења. Између песништва француског и хрватског песника постоје контактни, генетички утицаји, али и типолошкоаналошке сличности, будући да оба песника припадају оквирима исте поетичке и филозофске традиције. Матоша и Бодлера везују и формалне карактеристике - стилско савршенство и беспрекорна углађеност стиха. Значење песама постиже се употребом истих стилских фигура - синестезија, симбола и метафора, а у основи обају текста стоји антропоморфизација и персонификација пејзажа, што значи да су песме и тематско-мотивски повезане. Побројани елементи сведоче о могућностима поуздане интерпретације песама „Везе” и „Јесење вече” у компаративном кључу, која ће продубити ученичка сазнања о песницима модерне у региону и свету и спречити да се тумачење ових песама претвори у површно и нејасно побројавање општих аналогија.

\section{3. Компаративно проучавање песме „Везе” Шарла Бодлера и „Јесење вече” Антуна Густава Матоша}

Компаративно проучавање песме „Везе” Шарла Бодлера и „Јесење вече” А. Г. Матоша има своје методолошко оправдање само уколико долази након часа на коме су се ученици упознали са основним одликама модерне. Неколико часова пре часа на коме се изучава поетика модерне, ученицима би се могли поделити истраживачки задаци. Сви ученици добијају задатак да прочитају кратке и информативне текстове о модерни, парнасовству, ларпурлатизму, симболизму и импресионизму, који се налазе у читанци. Ђаци заинтересованији за српски 
језик и књижевност добијају задатак да прочитају објашњење сваке од ових пет одредница у неком од речника књижевних термина. Дакле, један ученик треба да прочита текст везан за модерну и правце који јој припадају у Речнику књижевних термина Тање Поповић, други у Речнику књижевних термина Драгише Живковића, а трећи у Речнику књижевних термина који је објавио Нолит. Уколико постоји више ученика који би се прикључили раду, могуће је смањити број одредница по сваком ученику. Час обраде основних карактеристика модерне започиње функционалном наставниковом монолошком деоницом, у оквиру које се ученицима предочавају поетичке законитости модерне и њених праваца. Потом ђаци саопштавају разултате својих истраживања, односно пружају дефиниције које су прочитали у речницима. Остали ученици се труде да запазе које се кључне речи понављају у одредницима из сва три речника, и говоре шта су уочили наставнику, који све то бележи на табли. Суштина онога што јесте модерна и њени правци остаће записана на табли, те стога видљива ученицима цео час.

Када као наставну тему има модерну, настава српског језика и књижевности у великој мери корелира са наставом ликовне и музичке културе, стога се ученицима приказују репродукције импресионистичких и симболистичких сликара, а репродукују се и музичка остварења композитора тога доба. Тако се остварују захтеви савремене и мултимедијалне наставе, а такође се ученицима предочава модерна епоха која својом обухватношћу представља једну етапу у развоју људског духа. У оквиру тога часа, наставник помиње све представнике модерне и њених праваца, а истиче предводничку улогу коју има Шарл Бодлер, песник који је сковао термин модерност, како би изразио ефемерност и испразност градског живота деветнаестовековног Париза. Нарочито се истиче Бодлеров значај за конституисање модерног лирског субјекта, као и за формирање целокупног потоњег европског песништва. Овим инсистирањем на централној позицији Бодлерове поезије у култури деветнаестовековне Европе ученици се уводе у оно што ће бити тема идућег часа. Бодлерова поезија и француски симболизам у великој мери су обликовали поезију песника модерниста са српско-хрватског говорног подручја - Ракића, Дучића, Матоша, Диса. У овом тренутку, ученицима се дају истраживачки задаци везани за компаративно проучавање песме „Везе” Шарла Бодлера и „Јесење вече” Антуна Густава Матоша. Истраживачки задаци су формулисани као проблемска питања за размишљање, и усредсређују се на посматрање формално-стилског и тематско-мотивског склопа обеју песама. Ученици треба да се потруде да уоче на којим све нивоима је Бодлер утицао на Матоша, по чему су њихове две репрезентативне песме исте, по чему су сличне, а по чему се разликују. Истраживачки задаци треба да садрже и подстицај за бављење биографијом Шарла Бодлера и Антуна Густава Матоша, пошто се претпоставља да ће буран и узбудљив Бодлеров живот бити веома инспиришући ученицима за читање његове поезије. Бодлерова модерност огледа се у комбиновању елемената поетике барока, романтизма и парнасизма са декаденцијом и амбиваленцијом човека у епохи индустријске револуције. Бодлер је песничку збирку Цвеће зла објавио 1857. године и посветио ју је једном од водећих песника свога доба, Тео- 
филу Готјеу. Иако су ову збирку пратили прогони, забране и оптужбе због јавног неморала и скандала, она се профилисала као прекретничка у европској књижевности. Неколико деценија касније, млади песници су Бодлерова гледишта прихватили као мисао и естетику епохе, и у његовим схватањима уочили су свој поглед на свет. Антун Густав Матош средишња је личност хрватске модерне, стилске формације која је у књижевност ушла као радикална иновација, да би се потом убрзо европеизирала и модернизовала, интегришући у себе савремена струјања симболизма, модернизма и импресионизма, са великим ослонцем на француску књижевну културу од Бодлера до Малармеа. Естетицизам и изузетно високе књижевне норме постале су примарни критеријум вредновања (Шицел 1978: 164) у хрватској књижевности.

Након уводног часа и бројних припремних радњи помоћу којих су формиране повољне радне околности, у којима ће ученицима бити омогућено да на целовит начин приступају репрезентативним песмама, да их доживе на стваралачки начин и да их интерпретирају у доживљајној и истраживачкој улози, могуће је приступити самом тумачењу двеју песама великих песника. Најповољнија наставна ситуација је она у којој је могуће да, помоћу пројектора и power point презентације, текст обеју песама буде доступан у сваком тренутку испред ученика, како би стално били навођени на паралелно посматрање и поредбено проучавање песама. Уколико тако нешто није могуће остварити, довољно је да се пре часа или на његовом самом почетку испишу текстови обеју песама на табли.

Час започиње наставниковим и ученичким излагањима о биографијама Шарла Бодлера и А. Г. Матоша. Након тога, ученици се позивају да послушају наставниково изражајно и интерпретативно читање обеју песама:

\footnotetext{
Пажљиво саслушајте песму „Везе” Шарла Бодлера и „Јесење вече” А. Г. Матоша.. Допустите им да вас одведу у мистериозни свет интензивног доживљаја природе и инспиришу вас снагом проживљене поетске импресије. Како сте доживели песме? Шта вам се у њима највише допало? Каква су осећања ове песме у вама пробудиле? Који стихови су највише побудили вашу пажњу? Образложите да ли уочавате сличности у метричком устројству ових песама.
}

Пре читања поетских текстова, ученицима се саопштава да прво треба да саслушају песму „Везе”, па да забележе на папиру кључне речи и утиске које је ова песма побудила. Наставник упозорава ученике да доживљавају, запажају и тумаче симболику и песничко виђење света које, понекад скривено и недокучиво, понекад нисмо спремни да разумемо, схватимо и прихватимо. Након што послушају песму „Јесење вече” и запишу запажања која је ова песма изазвала, приступа се разговору са ученицима. Разговор о утисцима након читања дела методолошки је оправдано уколико представља припремну радњу, тј. увођење ученика у свет поезије. Разговор о доживљајима поводом песама треба да води ка томе да ученици започну дијалог о тону, односно доминантној лирској атмосфери која преовладава у њима. Ученици се већ сада подстичу на компаративно сагледавање лирског штимунга у песмама. Претпоставља се да ће ђаци након 
првог читања уочити да обе песме говоре о природи и раскошним сензацијама које постоје у њој. У обема песмама природа је персонификована, односно на њу се гледа као на нешто животворно и живодајно. У првом делу часа настоји се да ученици увиде и разлике на нивоу песничког осећања које ове две песме изражавају. Наиме, очекује се да ће ученици споменути да у песми „Јесење вече” влада атмосфера сете, туге, меланхолије, потиштености, суморности, елегичности и песимистичности. У песми „Везе” лирски субјекат, међутим, више инсистира на томе да видљиво није довољно за спознају света и живота, и покушава да превазиђе ограниченост света доживљеног само посредством чула.

У овом тренутку наставног часа, ђацима треба саопштити да Бодлер у својој чувеној песми „Везе” сугерише идеју о универзалном сагласју (везама) између видљивог света и језика симбола, који описује неку дубљу, невидљиву реалност. Ученици су на овај начин подстакнути на размишљање о односима између речи и осећања, мишљења и ставова, као и о могућности изрецивог и неизрецивог, моћи и немоћи речи са којима се човек свакодневно суочава. Претпоставља се да ђаци знају шта је симбол као стилска фигура. Симбол је увек вишезначан и садржи смисао који је прикривен. Смисао симбола је у наговештају који се не може значењски фиксирати, тј. симбол никада нема једнострано разрешење као алегорија, на пример.

Једна од основних сличности међу песмама, коју је веома лако уочити, јесте да су песме писане у истом песничком облику - сонету. Ученици ће га лако препознати, с обзиром на то да су имали прилике да се сусретну са њим читајући Петраркин Канцонијер. Петраркистички или италијански сонет се састоји од два катрена и два терцета, а стих је најчешће једанаестерац (као што је и у Матошевој песми, док је у Боделровој дванаестерац - александринац). За италијански сонет карактеристично је да у терцетима долази до наглог преокрета у мислима у односу на завршницу катрена. Такође, рима из катрена никада се не преноси у терцете, што чини сонет асиметричном дводелном структуром. Уочавање истоветности метричке структуре двеју песама условиће њихово лакше читање и праћење промена у лирској атмосфери песама. Ученици се потом позивају да обрате пажњу на први катрен у сонетима:

\footnotetext{
Пажљиво прочитајте први катрен песме „Везе” и песме „Јесење вече”. Посебно се усредсредите на визуелни план песама. Шта дочарава слика природе као храма? Протумачите значење метафоричког исказа „Природа је храм”. Установите на који начин је природа оживљена у првој строфи песме „Јесење вече”. Утврдите шта све песнички субјекти обеју песама персонификују. Објасните какав се ефекат постиже коришћењем персонификације. На које се све начине визуелни и симболички план приближавају и преплићу?
}

Овим питањима ученици су мотивисани да, попут песника, природу доживе као храм, својеврсно свето место које води у метафизичке (оностране) пределе. Ученици увиђају да све што виде око лирског субјекта представља један симбол, чије значење трансцендира (превазилази) искуство, остварујући се у антиципацији и сугестији, а не у свом појавном облику. Идеја да се у материјалном свету крије некакво апстрактно значење није нова у историји културе, будући да ју је 
развио шведски теолог Сведенборг, да би нашла плодно тле у западноевропској и америчкој књижевности, од Балзака и Е. Т. Хофмана до Нервала и Јејтса (Рајт 2014: 45). Човек је окружен појавама које се налазе у свету природе. Иако су му оне биле одувек дате и свуда су присутне, човек их у брзини или устаљеном ритму сопственог живота не примећује или их не разуме. С обзиром на то да је природа представљена као шума симбола, ученицима ће „стубови живи” изгледати као стабла дрвећа у шуми нејасних и мутних речи. Ученици треба да одгонетну зашто је песничко ја изабрало да употреби баш реч „стуб”. Присећајући се да стубови у обичном животу представљају елементе архитектуре који спајају под са таваницом, ученици ће боље разумети поетску обраду овог мотива. Ђаци ће схватити да стубови у Бодлеровој песми означавају својеврсне пријемнике, односно све оно што спаја реалност овога света са невидљивим светом који се само слути. Симболи човека срећу „присним погледима”, што сведочи да у песничкој визији симболи, чије значење треба докучити, позивају људски дух да их протумачи. Ако нас симбол гледа присним погледом, значи да смо ми познати њему, и он нама, тј. да тумачење симбола представља надоградњу смисла који ми у њему самом већ уочавамо и који је очигледан и саморазумљив.

Што се песме „Јесење вече” тиче, претпоставља се да ће се ученици прво осврнути на мотив облака из прва два стиха. С обзиром на то да они оловне и тешке снове снивају, можемо их замислити као изразито ниске, густе и тамносиве. Облаци су персонификовани, а њихов сан упућује на прелазно стање између смрти и живота, односно између овостраног и оностраног. Постојање два света (онтолошки дуализам) јесте оно што у нашој свести директно евоцира Бодлерову поезију. Док су облаци беличасто сиви, тамне горске стране евоцирају зелену, мрку и црну боју. Следећи мотив јесте мотив сенки, које ће ученици препознати као симбол који упућује на оно што је тамно, тајанствено, мистериозно, илузорно и привидно. Постојање сенки, слично као и мотив сна, још једном подсећа на метафизичку другост на коју наилазимо у песми „Везе”. Ђаци ће уочити да сене пливају, у чему се огледа динамизам пејзажа и поетички акценат на неухватљивости тренутка. Покрет, међутим, ипак бива угашен епитетом монотоне, што сугерише то да је атмосфера једнолична и суморна упркос кретању. Крећу се и сенке и река која тече, али тиме што је описана као жута, она губи своју животност и уклапа се у сивило јесењег пејзажа. Нису животне ни гране, које су голе, што упућује на смрт природе. Слика природе у Матошевој песми је суморна, али су боје којим је представљена веома живе и креирају раскошну лепоту, што такође одговара бодлеровској визији света. Визуелни и симболички план су испреплетени, на тај начин што све што је у природи није баш онако како изгледа, већ се у свему могу ишчитати додатна значења и скривене поруке. Ученицима се поставља захтев да обрате пажњу на други катрен песама „Везе” и ,Јесење вече":

Запазите на који су начин у песми „Везе” повезани мириси, боје и звукови. Зашто је јединство које они чине „мрачно”, „дубоко” и „огромно”? Каква је природа разговора који воде различита чула? Које чулне сензације запажате у другом катрену песме „Јесење вече”? 
Наведите особине колорита заступљеног у овој строфи песме А. Г. Матоша. Како палета боја коју песнички субјекат користи утиче на тон који преовладава?

Ученици ће пажљивим читањем доћи до закључка да се у поетској представи песничког субјекта Шарла Бодлера аудитивне, визуелне и олфакторне сензације међусобно прожимају и комуницирају између себе, стварајући јединство „огромно ко ноћ и као светлост”. Лирско „ја” сугерише читаоцима да је природа сложена целина у којој између боја, мириса и звукова влада принцип сагласја. Чула превазилазе сопствену ограниченост сједињујући се у целину. Управо је човек тај који је у стању да снагом имагинације све те доживљаје обједини и оствари узајамност чулних утисака. Јединство боја, звукова и мириса је „мрачно” и „дубоко”, зато што превазилази расцепканост у сазнавању света која је последица деловања сваког чула понаособ. Тек кад се оствари пуноћа сагледавања појава у свету кроз мешање сензација, могуће је уочити свеопшту повезаност свега са свим. Везе које постоје између свих ствари односно укидање границе између чула Бодлер је називао универзалним аналогијама. Ослањајући се на романтичарско схватање имагинације као супериорне интелектуалне способности, Бодлер тврди да песничко ја свемир посматра као складиште слика и да је захваљујући машти способно да поетски обради оно што нађе у тој ризници.

Од свих сензација, ученици ће лако приметити да су у песми „Јесење вече” највише заступљене визуелне, тј. да у Матошевом песничком пејзажу доминирају различите боје. У другом катрену песме још једном се јавља жута боја, овога пута као помешана са црвеном, розе и наранџастом, које су дате у оквиру песничке слике сунца које крвари и умире у ранама. Тамни колорит доминира и у другој строфи, што се очитује у слици мрких врба које се црне црним вранама. Готово један за другим ређају се два облика речи црн, што потцртава преовлађујућу боју у другој строфи. Важно је да ученици разумеју да је дата разноврсност нијанси сличних или истих боја, у чему се огледа непостојаност тренутка коју су импресионисти желели да ухвате и опишу. Стилска фигура на којој је изграђена песничка визија пејзажа у обема строфама јесте персонификација. Облаци снивају, сенке пливају, док сунце умире и посматра - ови примери сведоче о антропоморфизацији пејзажа. То очовечење природе на најбољи начин показује прожимање природе и људи и испитује њихов однос и повезаност. Везе између природе и људи описане у овој песми посведочују Бодлерову теорију о универзалним аналогијама, која је мистичког порекла, будући да тврди да су све појаве на овом свету повезане тајним везама. Ученици су већ уочили сан и сенку као важне мотиве који доприносе мистериозности песме, а њима треба придодати и мотив магле, која скрива и собом повезује „кућице и торањ” у Матошевој песми. Најважнији тренутак за разумевање песама у целости јесте тумачење новина које доносе терцети Бодлерове и Матошеве песме:

Којим језичким и стилским средствима Бодлер постиже сугестију неразлучивог јединства различитих облика појавности чула? Како тумачите тврдњу песничког субјекта да су неки мириси „зелени ко поља, благи ко обое”? Чиме песник илуструје став о узајамној аналогији и складностима најразличитијих чулних утисака? 
По чему се први терцет песме „Јесење вече” разликује од претходних строфа? Набројте сличности и разлике између овог терцета и двају катрена. Разјасните зашто је у Матошевој песми за суштину људског бића везано осећање немира, неспокојства и несигурности.

Пре тумачења Бодлерових терцета, од изузетне важности је информисање ученика о синестезији, стилској фигури изузетно важној за симболизам. Синестезија је, наиме, специфична метафорична замена појмова којима се означавају чулни доживљаји, тј. опис перцепције у којем се осети једног чула изражавају категоријама другог чула. Утисци уметника су производи најразличитијих осећања, у којима су подједнако заступљене слике, мириси, звуци и боје. Сваки чулни утисак доноси непоновљиво искуство које је тешко, а понекад и немогуће исказати речима. Синестезија, и поезија у којој се она остварује, омогућавају да се искаже неизрециво, да се наслика невидљиво и објави оно што се не чује. Након те напомене, ученици ће врло једноставно идентификовати синестезије у Бодлеровој песми. Када песнички субјекат окарактерише мирисе као „зелене ко поља", он олфакторни (мирисни) опажај региструје као визуелни, а када тврди да су мириси „благи ко обое”, онда мирис објашњава путем звука, тј. уводи аудитивне елементе. Коришћењем синестезије песнички субјекат најјасније илуструје идеју о универзалним аналогијама и дубоком јединству у којима стоје мириси, звуци и боје. Ученици ће увидети да лирско „ја”, желећи да докаже да не постоје границе између чула, користи репертоар средстава за опис слике и звука не би ли дочарао квалитет мириса о коме пева. Ученици схватају да је лирски субјект обогатио опис мириса тако што га је упоредио са зеленом бојом и звуком обое, али и са мекоћом додира детиње коже, чиме је исказана тактилна сензација. Песнички субјект могао је назвати мирис благим, нежним, неприметним или неупадљивим, али поетски ефекат и убедљивост тих стихова онда не би били толико јаки. У последњем стиху првог терцета Бодлерових „Веза” читамо о мирисима који су „искварени, победнички, тежи”, у чему се огледа антропоморфизација мирисних утисака. Људи су ти који су искварени и победнички настројени, што сведочи да се у позадини Бодлеровог пејзажа крије прича о човеку.

На исти поступак очовечења наићи ћемо и у песми „Јесење вече”. Први стих терцета: Све је мрачно, хладно; у првом сутону, као да поентира расположење које је сугерисано претходним катренима. Основна разлика између првог терцета и катрена, међутим, заснива се на томе што се центар промишљања лирског субјекта помера са природе на човека, што се запажа нарочито у стиховима: Тек се слуте иесте, док не утону / У даљине слијепе људских немира. Пут који песничка свест описује није више део пејзажа, већ постаје симбол људских тежњи, намера, циљева и жеља, које човека стално гоне ка њиховом извршењу и испуњењу, што је тачка у којој се пресецају значења Бодлерове и Матошеве песме. Са објективне слике света, лирско ,jа” прелази на субјективну слику унутрашњег бића човека, чију суштину чине немир и стална потреба за трагањем и сазнавањем. Ученици уочавају да је у тим стиховима преокрет у значењу песме, jep се тек овде открива да песма „Јесење вече” говори о страху и упитаности 
који карактеришу сваког човека, а не о суморној и хладној природи у очекивању зиме. Завршницу интерпретације чини тумачење последњих терцета песама „Везе” и „Јесење вече":

Које мирисе лирски субјекат идентификује као „искварене, победничке, теже”? Размислите по чему се ти мириси разликују од нежних и благих о којима је било речи у претходној строфи. Објасните Бодлерову песму као пример тренутка у коме песничко надахнуће уобличава визију смисла и сагласја света. Аргументујте став да песма „Везе” илуструје тренутак откровења (епифаније).

Кога све може представљати горди јаблан из Матошеве песме? Образложите на који начин разумете да јаблан „шапће о животу мраком глухијем”. Зашто је јаблан усамљен?

„Везе” представљају Бодлерово холистичко (целовито) виђење стварности. Јаблан из Матошеве песме представља истакнутог човека, песника и њему слично продуховљено биће, које има већу свест и медитативнију природу од већине људи. Јаблан је горд, зато што је јединствен, изузетан. Он је виши од осталог дрвећа и због тога загледанији у небеске висине. Ова строфа показује како песниково око види уобичајен јесењи призор и како га поетским језиком онеобичава. У обичном дрвету чије суво лишће шушти на јесењем ветру, песничка имагинација види издвојено и посебно биће које шапће о само њему разумљивим тајнама живота и постојању света који превазилази свакодневно искуство. У Матошевој песми представљено је прожимање човека и природе, њихова нераскидива сједињеност и стопљеност. Ученици ће уочити да је синтагма „мраком глухијем" обликована путем синестезије, јер се визуелна слика представља на аудитивном плану - звуком, што још једном потврђује тезу да је Бодлер утицао на Матоша. Крај Матошеве песме враћа ученике на почетак Бодлерове. Наиме, јаблан у Матошевој песму има исту функцију и смисао као и „стубови живи” у Бодлеровој песми, отелотворавајући везу између појавног и непојавног света. Након свега реченог, ђацима ће постати јасно да тумачење Бодлерове песме у великој мери олакшава разумевање Матошеве песме, пружајући потпунији увид и богатство различитих значења.

\section{4. Закључак}

На примерима наставних часова на којима се обрађује Бодлерова и Матошева поезија у овом раду показано је да је за ваљано проучавање лирских песама са ученицима неопходно активирати што више методичких принципа, наставних метода и облика рада. Због малог обима а језгровитог језика лирике, проучавање лирске песме у настави захтева непрестано позивање и освртање на текст, тако да је током наставних часова неопходно у великој мери користити текстовну методу. Ученици су подстицани да запажају битне одлике програмских песама Шарла Бодлера и А. Г. Матоша, да их тумаче и да увиђају промену до које је дошло на плану песничког израза у односу на претходну епоху и песничку традицију. Ученици су мотивисани да уоче нова стилска изражајна средства и да их тумаче у контексту естетике модерне. Код њих се развија способност разуме- 
вања вишезначности песничког текста, појава и тема које су у њему аутентичне, сложене и разноврсне. Компаративно тумачење песама „Везе” и „Јесење вече” продубљује ученичка сазнања о песништву модерне на нашим просторима и у свету, чиме се поредбени метод показује као сврсисходан у савременој настави књижевности.

\section{ЛИТЕРАТУРА}

Бајић 2004: Љ. Бајић, Одабране наставне интерпретаичје, Београд: Друштво за српски језик и књижевност Србије.

Голијанин-Елез 2009: С. Голијанин-Елез, Лирски циклуси и песничке збирке у савременој настави књижевности: наставни рад на лирским циклусима и збиркама Миодрага Павловића, Васка Попе, Бранка Миљковића и Стевана Раичкоића: докторска дисертаиија, Нови Сад.

Ilić 1980: P. Ilić, Lirska poezija u savremenoj nastavi, Novi Sad: Radnički univerzitet „Radivoj Ćirpanov”.

Миловановић 2016: С. Миловановић, Савремена истраживања ауторске лирике у средюошколској настави: докторска дисертаџија, Београд.

Николић 2009: М. Николић, Методика наставе српског језика и књижевности, Београд: Завод за уџбенике и наставна средства.

Oraić-Tolić 1990: D. Oraić-Tolić, Teorija citatnosti, Zagreb: Grafički zavod Hrvatske.

Рајт 2014: Б. Рајт, Бодлерово песничко путовање у „Цвећу зла”, Нови Сад: Поља: месечник за уметност и културу, год. 59, бр. 487, 43-59.

Rosandić 1975: D. Rosandić, „Metodički pristup lirskoj poeziji u osnovnoj školi”, u: D. Rosandić (red.), Metodički pristup književnoumjetničkom tekstu: lirika (priručnik za nastavnike srpskohrvatskog - hrvatskosrpskog jezika u osnovnoj školi), Sarajevo: Veselin Masleša.

Rosandić 1988: D. Rosandić, Metodika književnog odgoja i obrazovanja, Zagreb: Školska knjiga.

Тарановски 1982: К. Тарановски, Къига о Мандељитаму, Београд: Просвета.

Фридрих 2003: Х. Фридрих, Структура модерне лирике, Нови Сад: Светови.

Šicel 1978: M. Šicel, Povijest hrvatske književnosti, knj. 5, Književnost moderne, Zagreb: Liber.

Штајгер 1978: Е. Штајгер, Умеће тумачења и други огледи, Београд: Просвета. 
Sofija P. Simović

\author{
STUDY OF LYRIC POETRY IN LITERATURE TEACHING: A COMPARATIVE \\ APPROACH ON THE EXAMPLE OF THE POEMS "CORRESPONDENCES” \\ BY CHARLES BAUDELAIRE AND “AN AUTUMN EVENING” \\ BY ANTUN GUSTAV MATOŠ
}

\begin{abstract}
Summary
This paper presented the course of one school class in which comparative method was used to study the poems "Correspondances" by Charles Baudelaire and "Autumn Evening" by Antun Gustavo Matos. At the very beginning of the paper, a theoretical overview of the characteristics of lyric poems was given, showing the differences between this and other literary genres. Afterwards, the specificities and problems of studying poetry in high school were enumerated, as well as the importance of valid motivation of pupils for reading, experiencing and interpreting the lyric poem, since this genre is not a favorite for them. Special attention was paid to the numerous teaching goals that can be achieved by an adequate methodical approach to poetry. In the next section, the distinction between closed and open approach to the literary text was established, and the necessity of intertextual and comparative approach was asserted. After that, some of the integration factors that enable the quality dynamics of the interpretation of Baudelaire's and Matos' poems were introduced to the paper. The conclusion that occurs, after a comparative interpretation of the poems of the Croatian and the French modernist, is that the pupils will be encouraged to develop reading interests related to poetry, as well as creative activities based on the interpretation of lyric poems.

Key words: methodology, teaching, modernism, poetry, South Slavic literature, A. G.
\end{abstract} Matos, Charles Baudelaire, comparative approach. 